\title{
Production and Evaluation of Some Bioactive Compounds Extracted from Squilla (Oratosquilla massavensis) Shells
}

\author{
Abouzeed A. S. ${ }^{1,}$, , Omayma E. Shaltout ${ }^{2}$, Ibrahim S. M. ${ }^{1}$, Attia. R. S. ${ }^{3}$, Aboul-yazeed A. M $^{2}$ \\ ${ }^{1}$ Fish Processing and Technology Lab., Fisheries Division, National Institute of Oceanography and Fisheries, Alexandria, Egypt \\ ${ }^{2}$ Department of Food Science and Technology, Faculty of Agriculture, Saba Basha, Alexandria University, Alexandria, Egypt \\ ${ }^{3}$ Department of Food Science and Technology, Faculty of Agriculture, El-Shatby, Alexandria University, Alexandria, Egypt
}

\section{Email address: \\ abozeed_niof@yahoo.com (Abouzeed A. S.)}

\section{To cite this article:}

Abouzeed A. S., Omayma E. Shaltout, Ibrahim S. M., Attia. R. S., Aboul -yazeed A. M. Production and Evaluation of Some Bioactive Compounds Extracted from Squilla (Oratosquilla massavensis) Shells. American Journal of Life Sciences. Special Issue: New Horizons in Basic and Applied Zoological Research. Vol. 3, No. 6-1, 2015, pp. 38-44. doi: 10.11648/j.ajls.s.2015030601.16

\begin{abstract}
This work was performed to investigate the production and physicochemical properties of some bioactive compounds (chitin, chitosan and astaxanthin) extracted from squilla (Oratosquilla massavensis) shells. Chemical composition of squilla shells and chitin yield were determined. Results showed that pre-treated squilla shells contained $68.11 \%$ moisture, $12.88 \%$ true protein, $4.79 \%$ crude fat and $44.59 \%$ ash content (on dry weight). Chitin yield and its ash content ranged between $15.75-16.08 \%$ and $0.81-1.26 \%$, respectively. The physicochemical properties of chitosan at different times and temperatures showed that chitosan composed $8.73-11.19 \%$ moisture, $0.66-0.83 \%$ true protein, $0.14-0.25 \%$ ash content. Viscosity of chitosan at higher temperatures $\left(120^{\circ} \mathrm{C}\right.$ and $\left.130^{\circ} \mathrm{C}\right)$ for different times $(30 \mathrm{~min}$ and $60 \mathrm{~min})$ were significantly $(P<0.05)$ lower (80-111 cps) than the lower temperatures $\left(100^{\circ} \mathrm{C}\right.$ and $\left.110^{\circ} \mathrm{C}\right)$ for $60 \mathrm{~min}(138-130 \mathrm{cps})$. At $120^{\circ} \mathrm{C}$ and $130^{\circ} \mathrm{C}$, for $30 \mathrm{~min}$, solubility was significantly lower (93.5-95.6\%) than all other temperatures and times used. The degrees of deacetylation (DD) were significantly different at $130^{\circ} \mathrm{C}$ for $30 \mathrm{~min}$ and $60 \mathrm{~min}$ than all other temperatures and times used being higher than $70 \%$ and ranged $73.11 \%-84.68 \%$. Average molecular weight (MW) of chitosan at $120^{\circ} \mathrm{C}$ for 30 min was significantly different than all times and temperatures used except $120^{\circ} \mathrm{C}$ for $60 \mathrm{~min}$ and as high as $130^{\circ} \mathrm{C}$ for $60 \mathrm{~min}$. Thus, it is obvious that MW ranged 180-189 Kilo Dalton was significantly different than lower Mw value (134.8 KD). A high value of water binding capacity (WBC) was found at $120^{\circ} \mathrm{C}$ for 60 min while fat binding capacity was found at $120^{\circ} \mathrm{C}$ for 30 min and 60 min compared with other treatments. Concerning the carotenoids, it was found that the astaxanthin in female gonads exhibited higher carotenoid concentration $(14.01 \mu \mathrm{g} \backslash \mathrm{g})$ than the shells $(10.10 \mu \mathrm{g} \backslash \mathrm{g}$ on wet weight). In conclusion, squilla shells are highly prized as an inexpensive market value which could be converted into a valuable expensive chitosan and female gonads are considered a good source for carotenoids, particularly astaxanthin.
\end{abstract}

Keywords: Physicochemical, Properties, Squilla, Chitin, Chitosan, Astaxanthin

\section{Introduction}

Huge quantities of inexpensive varieties of squilla spp (Crustacea, squillidae) are caught as by-catch and they are not properly utilized. The total squilla spp. production from only the Mediterranean Sea catch during 2013 was 215 tons [1]. Chitin extracted from the exoskeleton of crab, squilla, and shrimp, could be used in a variety of applications especially when transformed into the more useful compound chitosan. The increased use of the biopolymer, have been gaining importance as raw materials in many industrial sectors such as food, textile, packaging, medicine and pharmacy. Biopolymers play crucial roles in applications where the materials are in direct contact with body tissue [2] Also, chitin ( $\beta$-(1-4)-2-acetamido-2-deoxy-D-glucopyrnaose) is the second most abundant natural biopolymer generally obtained from exoskeletons of crustaceans such as crabs, shrimp, lobsters and krill. The most important derivative of chitin is chitosan $((1,4)-2$-amino-2-deoxy- $\beta$-D glucose $)$ obtained by excessive deacetylation of chitin with alkali. Chitosan, the linear polymer of D- glucosamine in $\beta-(1-4)$ linkage has been recommended as a suitable functional material because of its biocompatibility, biodegradability, non-toxicity, adsorption properties and regulation of cell activation. Due to its antimicrobial activity, chitosans have 
many pharmaceutical applications and generally used as natural preservative for the safety of food [3-5]. Crustacean exoskeleton is an important natural source of carotenoids, particularly astaxanthin. Several studies have been carried out to recover the pigment from crustacean processing discards. Methods of extraction of carotenoids using organic solvents and edible oils have been attempted [6].The antioxidant activity of carotenoid-containing protein isolate from crustacean wastes was studied. The conditions for isolation of antioxidant-rich carotenoprotein from shrimp heads using an autolytic process were optimized. Also, the antioxidant activity of shrimp carotenoid extract indicated its potential for use as a natural antioxidant for use in food and biomedical applications [7]. In the family of crustaceans, squilla is another candidate that has not been explored as a source of chitin and chitosan. It is a by-catch with an extremely low economic value and is available in large quantities in the seas of countries in the tropical regions [8]. Therefore, the current research was performed to make the utmost utilization of Oratosquilla massavensis for the production of some bioactive component. This can be achieved in the present study by extracting chitosan from the shells and astaxanthin from both shells and gonads and determine the physicochemical properties of the extracted chitosan.

\section{Materials and Methods}

About $30 \mathrm{~kg}$ fresh squilla (Oratosquilla massavensis) samples were purchased from the commercial catch at El-Anfoshy landing place, Alexandria, Egypt during the period from May to December, 2014. They were transported using icebox to the Fish Processing and Technology Lab., National Institute of Oceanography and Fisheries, Alexandaria. Fresh squilla samples were frozen at $-30^{\circ} \mathrm{C}$ in an Air Blast Freezer for about 10 minutes, after thawing the shells were removed by scissors from the abdominal region up to the thoracic region. Flesh was utilized to obtain some fishery products. Shell wastes was packed in polyethylene bags and stored at $-18^{\circ} \mathrm{C}$ until utilized. Frozen shells were thawed at ambient temperature, steamed for $10 \mathrm{~min}$, blended with tap water $(1: 1 \mathrm{w} / \mathrm{v})$ using a mixer (Malounix, Jeannette 243 France) to remove undesirable organic matters, adherent proteins and other impurities. Samples were dried at $70^{\circ} \mathrm{C}$ overnight then grinded. Ground shells were placed in tightly closed glass jars and stored at ambient temperature until analysis.

\subsection{Extraction of Chitin and Chitosan}

Two techniques were performed for chitin extraction as reported by [9]. Squilla shells were subjected to two production techniques ( $\mathrm{A}$ and $\mathrm{B}$ ). In technique $\mathrm{A}$; demineralization by $3 \% \mathrm{HCl}$ was done twice for $3 \mathrm{~h}$ and $4 \%$ $\mathrm{NaOH}$ treatment during $24 \mathrm{~h}$ was given between the two $\mathrm{HCl}$ treatments. As inverse to technique $\mathrm{A}$, the technique $\mathrm{B}$ was started with deproteinization with $4 \% \mathrm{NaOH}$ twice $(12 \mathrm{~h}$ for each period) $\mathrm{HCl}$ treatment $(4.5 \%, 6 \mathrm{~h})$ was given in between. In the present study, chitosan was obtained from chitin extracted from technique $\mathrm{A}$ by deacetylation $(50 \% \mathrm{NaOH}$ at $100,110^{\circ} \mathrm{C}$ for $60 \mathrm{~min}$ and $120,130{ }^{\circ} \mathrm{C}$ for $30-60 \mathrm{~min}$. Fig. (1) shows the technique steps of chitosan production as described by [10].

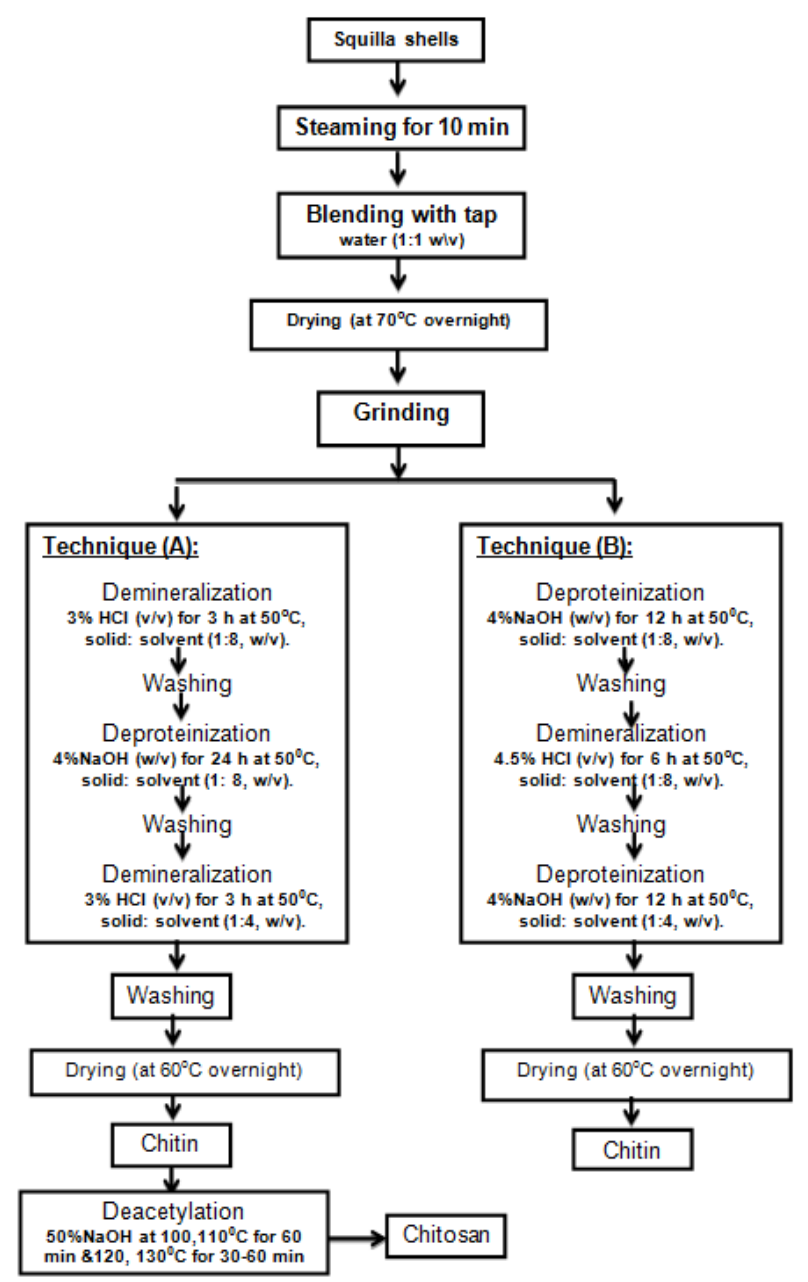

Fig. (1). Flowchart of chitosan extracted from squilla shells.

\subsection{Extraction of Carotenoids (as Astaxanthin)}

Total carotenoids were determined according to the method described by [6]. A known weight of homogenized wet squilla shell $(2 \mathrm{~g})$ was extracted with $20 \mathrm{ml}$ of acetone and centrifuged at $3500 \mathrm{rpm}$ for 5 minutes. The supernatant was conserved while the precipitate was re-extracted several times, until the acetone extract became colorless. The pooled supernatant was transferred to approximately $25 \mathrm{ml}$ of petroleum ether in a separation funnel. The petroleum phase, containing the carotenoids, was washed several times with $2 \%$ $(\mathrm{w} / \mathrm{v}) \mathrm{NaCl}$ solution, filtered through anhydrous sodium sulphate and diluted to $25 \mathrm{ml}$ final volume with petroleum ether. The absorbance (A) of the carotenoid extract in petroleum ether was measured at $467 \mathrm{~nm}$. Total carotenoid (as astaxanthin of wet squilla shell) was calculated as:

Total carotenoid (as astaxanthin) $\mu g^{-1}=\left(\mathrm{A}_{467}\right)(\mathrm{D})(\mathrm{V}) / 0.2400(\mathrm{~W})$ 
Where: $\mathrm{A}_{467}=$ The absorbance at $467 \mathrm{~nm}$ in a $\mathrm{cm}$ light path; $\mathrm{D}=$ Dilution factor of sample prior to spectral analysis; $\mathrm{V}=$ The volume of petroleum ether containing pigments (normally $25 \mathrm{ml}$ ); W = Weight of sample; and Value (0.2400) $=$ The extinction coefficient of astaxanthin in petroleum ether

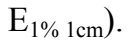

\subsection{Analytical Methods}

\subsubsection{Chemical Composition of Squilla Shells}

Chemical composition as moisture content, crude fat and ash content of the shells were determined according to [11]. True protein was determined by using standard Biuret protein assay with Bovine Serum Albumin (Sigma, St. Louis, MO) as standard [12]. Moisture content of the extracted chitosan was determined at $60^{\circ} \mathrm{C}$ overnight according to the gravimetric method as described by [13].

\subsubsection{Degree of Deacetylation (DD}

Degree of Deacetylation (DD) of chitosan was characterized by Fourier Transform Infrared (FTIR) Spectroscopy in the range of 500 to $4000 \mathrm{~cm}-1$ (Brucker Tensor 37) as described by [14]. Ten $\mu \mathrm{g}$ samples were mixed with $100 \mu \mathrm{g}$ of dried Potassium Bromide $(\mathrm{KBr})$ and compressed to prepare a salt disc $(10 \mathrm{~mm}$ diameter). The absorbance of IR spectrum at 1637 and $3430 \mathrm{~cm}^{-1}$ were measured to calculate the DA according to the following equation:

$$
\begin{gathered}
\mathrm{DA}(\%)=100-\left(\mathrm{A}_{1637} / \mathrm{A}_{3430}\right) \times 115 \\
D D(\%)=100-\mathrm{DA}(\%)
\end{gathered}
$$

\subsubsection{Average Molecular Weight}

Molecular Weight (MW) average of the viscosity (Dalton) was determined, the chitosan was dissolved in a mixture of $0.1 \mathrm{M}$ acetic acid with $0.2 \mathrm{M} \mathrm{NaCl}$, and then the automated solution viscometer was used to measure the intrinsic viscosity $(\eta)$. The Mark-Houwink equation relating to intrinsic viscosity with empirical viscometric constants $\mathrm{K}=1.81 \times 10^{-3} \mathrm{~cm}^{3} / \mathrm{g}$ and $\mathrm{a}=0.93[15]$ for chitosan was used to calculate the molecular weight using the following equation: $[\eta]=\mathrm{KM}^{\mathrm{a}}$

\subsubsection{Viscosity of Chitosan}

Viscosity of chitosan was determined with a Myr Rotary Viscometer Series VR 3000 (Model V1-L) as reported by [16]. Chitosan solution was prepared in $1 \%$ acetic acid at a $1 \%$ concentration on a dry basis. Measurement was made in duplicate using a No. 1 spindle at $50,100 \mathrm{rpm}$ on solutions at $25^{\circ} \mathrm{C}$ with values reported in centipoises (cps) units.

\subsubsection{Solubility of Chitosan}

Solubility of chitosan was measured using the modified method of [17] and determined by dissolving $1 \%(\mathrm{w} / \mathrm{v})$ chitosan in a solution of $1 \%$ glacial acetic acid with continuous stirring for $24 \mathrm{~h}$. The solution was centrifuged to determine the \% insoluble chitosan. Squilla chitosan powder $(0.1 \mathrm{~g}$ in triplicate) were placed into a centrifuge tube (known weight) then dissolved with $10 \mathrm{ml}$ of $1 \%$ acetic acid for 30 min using an incubator shaker operating at $240 \mathrm{rpm}$ and $25^{\circ} \mathrm{C}$ The solution was then immersed in a boiling water bath for 10 minutes, cooled to room temperature $\left(25^{\circ} \mathrm{C}\right)$ and centrifuged at $10,000 \mathrm{rpm}$ for $10 \mathrm{~min}$. The supernatant was decanted. The undissolved particles were washed in distilled water $(25 \mathrm{ml})$, and then centrifuged a 10,000 rpm. The supernatant was removed and undissolved pellets dried at $60^{\circ} \mathrm{C}$ for $24 \mathrm{hr}$. Finally, the particles were weighed and determined the percentage solubility according to the following equation:

$\%$ solubility $=$ (Initial weight of tube + chitosan $)-($ Final weight of tube + chitosan $) \times 100$ (Initial weight of tube + chitosan) - (Initial weight of tube)

\subsubsection{Water and Fat Binding Capacities (WBC\& FBC)}

Water and fat binding capacities (WBC \& FBC) of chitosan were measured using a modified method of [18]. WBC \& FBC were initially carried out by weighing a centrifuge tube containing $0.5 \mathrm{~g}$ of sample, adding $10 \mathrm{ml}$ of water, and mixing on a vortex mixer for $1 \mathrm{~min}$ to disperse the sample. The contents were left at ambient temperature for 30 min with intermittent shaking for $5 \mathrm{sec}$ every $10 \mathrm{~min}$ and 38 centrifuged at 3,500 rpm for $25 \mathrm{~min}$. After the supernatant was decanted, the tube was weighed again. WBC \& FBC were calculated as follows:

WBC $(\%)=[$ water bound $(\mathrm{g}) /$ initial sample weight $(\mathrm{g})]$ x 100 .

FBC $(\%)=[$ fat bound $(\mathrm{g}) /$ initial sample weight $(\mathrm{g})] \times 100$.

\subsection{Statistical Analysis}

The obtained data were used for descriptive statistical analysis consisting of means \pm standard deviation of triplicates. In order to test the significance of physic -chemical properties of chitosan, one-way ANOVA test were applied and means were further differentiated by Duncan's Multiple Range Test [19] (SAS,2001). Means with the same letter for each parameter are not significantly different, otherwise they do $(\mathrm{P}<0.05)$.

\section{Results and Discussion}

\subsection{Chemical Compositions of Squilla Shells}

The chemical compositions of squilla (O. massavensis) shells are presented in Table (1).

Table (1). Chemical composition of squilla shells.

\begin{tabular}{lll}
\hline Constituent $(\%)$ & Wet weight $(\mathbf{W W})$ & Dry weight $(\mathbf{D W})$ \\
\hline Moisture content & $68.11 \pm 0.69$ & --- \\
True protein* & $4.11 \pm 0.41$ & $12.88 \pm 0.31$ \\
Crude fat & $1.53 \pm 0.19$ & $4.79 \pm 0.59$ \\
Ash content & $14.22 \pm 0.14$ & $44.59 \pm 0.44$ \\
\hline
\end{tabular}

Data are expressed as mean \pm S.D. of triplicates

* Determined by the method of Biuret [12].

Squilla shells contained $68.11 \%$ moisture, $12.88 \%$ protein, $4.79 \%$ fat and $44.59 \%$ ash (dry weight). Also, results in the present study are in accordance with the findings of [16] who 
reported that the chemical composition of squilla (S. empusa) shells were $71.3 \%$ moisture, $21.2 \%$ protein and $42.8 \%$ ash. In addition, [20] reported that the proximate composition (dry basis) of prawn waste was 75-80\% moisture, 30-35 \% ash, $35-40 \%$ protein and $3-5 \%$ fat.

\subsection{Chitin Yield and Ash Content}

Chitin yield and ash content of chitin. Table (2) shows the effect of two extraction techniques on chitin, chitosan yield and ash content.

Table (2). Effect of extraction techniques on Chitin yield and ash content of chitin.

\begin{tabular}{lll}
\hline Constituent (\%) & Technique (A) & Technique (B) \\
\hline Chitin yield & $15.75 \pm 0.21$ & $16.08 \pm 0.09$ \\
Ash content & $0.81 \pm 0.11$ & $1.26 \pm 0.23$ \\
Chitosan yield & 86.50 & 87.00 \\
\hline
\end{tabular}

Data are expressed as mean \pm S.D. of triplicates

Technique (A): decalcification by $3 \% \mathrm{HCl}$ was done twice for $3 \mathrm{~h}$ each and $4 \%$ $\mathrm{NaOH}$ treatment during $24 \mathrm{~h}$ was given between the two $\mathrm{HCl}$ treatments.

Technique (B): the squilla shell was deproteinated with $4 \% \mathrm{NaOH}$ twice for

12-h period each and $\mathrm{HCl}$ treatment $(4.5 \%, 6 \mathrm{~h})$ was given in between.

Results show that squilla shells from the pilot study represent about $60 \%$ by weight of the whole squilla whereas, the edible portion comprise $40 \%$. Results also show that
Chitin yield in the present study ranged between 15.75 $16.08 \%$ and its ash content ranged between $0.81-1.26 \%$, in addition, chitosan yield ranged $86.5-87.00 \%$ according to techniques (A\&B) applied, respectively (Table2).

These results are in agreement with [21] who reported that the average head and shell waste yield from the shrimp is around $60 \%$ by weight of the whole shrimp. And, it contained $15-40 \%$ chitin. Whereas, [22] reported $12-16 \%$ chitin content from squilla shell. As the matter of fact, [20] reported 15-20\% chitin content from prawn waste. [23] showed that the chitin content of the different sources may vary over a large range (from $7 \%$ with barnacles to $40 \%$ with squid pens). On the other hand, in this study, the yield of chitin extracted from squilla shells by two techniques was higher than those reported by [24] who found that the yield of chitin obtained from $20 \mathrm{~g}$ Oratosquilla nepa shell was $2.145 \mathrm{~g}(10.725 \%)$ while the shell yield of Oratosquilla quinquedentata was $2.125 \mathrm{~g}(10.625 \%)$.

\subsection{Physicochemical Properties of Chitosan}

The effect of both temperature and time using the conditions adopted in the flowchart of chitosan Fig (1), deacetylation by $50 \% \mathrm{NaOH}$ on physicochemical characteristics of chitosan are shown in Table (3).

Table (3). Effect of both temperature and time on physicochemical characteristics of chitosan.

\begin{tabular}{|c|c|c|c|c|c|c|c|}
\hline Treatments (temp.\& time) & Moisture (\%) & Ash (\%) & Protein $(\%)$ & Viscosity (cps) & Solubility (\%) & ${ }^{*} \mathrm{DD}(\%)$ & $* * M w(K D)$ \\
\hline $100^{\circ} \mathrm{C}(60 \mathrm{~min})$ & $8.73 \pm 0.48^{\mathrm{a}}$ & $0.135 \pm 0.03$ & $0.758 \pm 0.13$ & $138 \pm 2.83^{\mathrm{a}}$ & $98.27 \pm 0.67^{\mathrm{ab}}$ & $75.79 \pm 0.26^{\mathrm{d}}$ & $189.290 \pm 42.78^{\mathrm{a}}$ \\
\hline $110^{\circ} \mathrm{C}(60 \mathrm{~min})$ & $11.19 \pm 0.12^{\mathrm{b}}$ & $0.254 \pm 0.05$ & $0.825 \pm 0.13$ & $130 \pm 4.24^{\mathrm{a}}$ & $97.25 \pm 0.35^{\mathrm{ab}}$ & $73.11 \pm 0.84^{\mathrm{e}}$ & $184.174 \pm 24.43^{\mathrm{a}}$ \\
\hline $120^{\circ} \mathrm{C}(30 \mathrm{~min})$ & $10.85 \pm 0.60^{\mathrm{b}}$ & $0.218 \pm 0.04$ & $0.824 \pm 0.13$ & $80 \pm 2.83^{\mathrm{e}}$ & $93.5 \pm 2.12^{\mathrm{c}}$ & $82.25 \pm 0.11^{\mathrm{b}}$ & $134.855 \pm 27.61^{\mathrm{b}}$ \\
\hline $120^{\circ} \mathrm{C}(60 \mathrm{~min})$ & $10.91 \pm 0.02^{\mathrm{b}}$ & $0.201 \pm 0.03$ & $0.724 \pm 0.16$ & $100 \pm 4.24^{\mathrm{d}}$ & $98.8 \pm 0.57^{\mathrm{a}}$ & $84.68 \pm 0.82^{\mathrm{a}}$ & $172.335 \pm 39.36^{\mathrm{ab}}$ \\
\hline $130^{\circ} \mathrm{C}(30 \mathrm{~min})$ & $11.04 \pm 0.04^{\mathrm{b}}$ & $0.249 \pm 0.02$ & $0.656 \pm 0.13$ & $120 \pm 3.54^{b}$ & $95.6 \pm 0.85^{\mathrm{bc}}$ & $77.82 \pm 0.86^{\mathrm{c}}$ & $180.843 \pm 17.49^{\mathrm{a}}$ \\
\hline $130^{\circ} \mathrm{C}(60 \mathrm{~min})$ & $10.67 \pm 0.13^{\mathrm{b}}$ & $0.196 \pm 0.09$ & $0.662 \pm 0.13$ & $111 \pm 1.41^{\mathrm{c}}$ & $97.67 \pm 1.31^{\mathrm{ab}}$ & $78.65 \pm 0.64^{\mathrm{c}}$ & $163.943 \pm 29.38^{\mathrm{ab}}$ \\
\hline
\end{tabular}

Mean with different superscripts in a row or columns are significantly different at $(\mathrm{p}<0.05)$

*DD: degree of deacetylation

Deacetylation process in all treatments (time / temp) were performed using $50 \% \mathrm{NaOH}$

**Mw: average molecular weight (kilo Daltons)

\subsubsection{The Chemical Compsation of Chitosan}

The values of the moisture content of chitosan were 8.73, $11.19,10.91$, and $10.67 \%$ at $100,110,120^{\circ} \mathrm{C}$ and $130^{\circ} \mathrm{C}$ for $60 \mathrm{~min}$, respectively, whereas, values were 10.85 and $11.04 \%$ at $120^{\circ} \mathrm{C}$ and $130^{\circ} \mathrm{C}$ for $30 \mathrm{~min}$, respectively. On the other hand, results indicated that the moisture content at low temperature $\left(100^{\circ} \mathrm{C}\right.$ for $\left.60 \mathrm{~min}\right)$ was significantly lower than all other temperatures and times. Chitosan is hygroscopic in nature [25], hence it is very possible that the chitosan samples in the present study may be affected by moisture absorption during storage. According to [26], commercial chitosan products contain $\leq 10 \%$ moisture content. Concerning the ash content, values were $0.135,0.254,0.201$ and $0.196 \%$ at $100,110,120^{\circ} \mathrm{C}$ and $130^{\circ} \mathrm{C}$ for $60 \mathrm{~min}$, respectively. Also, values were 0.218 and $0.249 \%$ at $120^{\circ} \mathrm{C}$ and $130^{\circ} \mathrm{C}$ for $30 \mathrm{~min}$, respectively. The ash content in chitosan is an important parameter. Some residual ash of chitosan may affect their solubility, consequently contributing to lower viscosity, or can affect other more important characteristics of the final product. A high quality grade of chitosan should have less than $1 \%$ of ash content and less than $1 \%$ protein [10]. With regard to true protein content, the values were $0.758,0.825,0.724$ and $0.662 \%$ at $100,110,120$ and $130 \mathrm{oC}$ for $60 \mathrm{~min}$, respectively. Besides, for $30 \mathrm{~min}$, the values of true protein were 0.824 and $0.656 \%$ at 120 and $130 \mathrm{oC}$, respectively (Table 3 ). These results are in agreement with those reported by [16] who found that the chemical composition of chitosan extracted from squilla shells ranged between $10.4-10.7 \%$ moisture, $0.88-0.94 \%$ protein, and $0.14-0.23 \%$ ash content.

\subsubsection{Viscosity}

Viscosity of chitosan extracted from squilla shells, in the present study were 138, 130, 100 and $111 \mathrm{cps}$ at 100, 110, $120^{\circ} \mathrm{C}$ and $130^{\circ} \mathrm{C}$ for $60 \mathrm{~min}$, respectively. Also, values were 80 and $120 \mathrm{cps}$ at 120 and $130^{\circ} \mathrm{C}$, for $30 \mathrm{~min}$, respectively (Table 3). Higher temperatures $\left(120^{\circ} \mathrm{C}\right.$ and $\left.130^{\circ} \mathrm{C}\right)$ with 
different times (30 $\mathrm{min}$ and $60 \mathrm{~min}$ ) were significantly different from the lower temperature $\left(100^{\circ} \mathrm{C}\right.$ and $\left.110^{\circ} \mathrm{C}\right)$ for $60 \mathrm{~min}$. [27] reported that the viscosity of chitosan solutions in the literature generally ranges between $60-780 \mathrm{cps}$. In the present study under the different time and temperature conditions used viscosity ranged between $80-138$ cps. [28] reported that the chitosan viscosity was closely related to the deacetylation time and that the chitosan reached its highest viscosity with a short deacetylation time.

\subsubsection{Solubility}

Solubility Chitin is hydrophobic (water insoluble) as well as in most organic solvents. In contrast chitosan is soluble in dilute organic acids at low $\mathrm{pH}$ due to the free protonable amino groups present in the D-glucosamine units [29]. The percent of solubility of chitosan in the present study were $98.27,97.25,98.8$ and $97.67 \%$ at $100,110,120^{\circ} \mathrm{C}$ and $130^{\circ} \mathrm{C}$ for $60 \mathrm{~min}$, respectively. Whereas, they were 93.5 and $95.6 \%$ at $120^{\circ} \mathrm{C}$ and $130^{\circ} \mathrm{C}$, for $30 \mathrm{~min}$ respectively (Table 3). These results are in agreement with [16] they reported that high solubility chitosan ranged between 97.3\%-98.6\% obtained from Squilla empusa. [30] reported that the main limitations in the use of chitosan in several applications are its high viscosity and low solubility at neutral $\mathrm{pH}$. Results in the present study indicated that at $120^{\circ} \mathrm{C}$ and at $130^{\circ} \mathrm{C}$ for $30 \mathrm{~min}$ solubility was significantly lower than all other temperature $\&$ times used, this may indicate that at lower time (30 min) low solubility may be achieved. As a matter of fact high solubility value is reached at $120^{\circ} \mathrm{C}$ for $60 \mathrm{~min}$ being $98.85 \%$.

\subsubsection{Deacetylation Degree (DD)}

The deacetylation degree (DD) of chitosan is important for its use in the industry [26, 31]. Different temperatures and times used in the present study in determining the degree of deacetylation were significantly different than $130^{\circ} \mathrm{C}$ for 30 min and $60 \mathrm{~min}$. In the present study the DD were higher than $70 \%$ ranging between $73.11 \%-84.68 \%$. According to [10], DD of chitosan ranges between $56 \%$ - 99\% with an average of $80 \%$. From this regard, certain researchers suggested that the term chitosan should be used when the degree of deacetylation is above $<75 \%$ [32]. [33] found that the DD of the commercial chitosan and the extracted chitosan from $M$. stebbingi shells were determined as $86.92 \%$ and $92.19 \%$, respectively, by the elemental analysis and potentiometric titration.

\subsubsection{Chitosan Average Molecular Weight (MW)}

The molecular weight (MW) of chitosan is one of the most important properties as it considerably affects the physicochemical and functional properties [34]. In the present study, temperature at $120^{\circ} \mathrm{C}$ for $30 \mathrm{~min}$ was significantly different than all times and temperatures used except $120^{\circ} \mathrm{C}$ for $60 \mathrm{~min}$ and as high as $130^{\circ} \mathrm{C}$ for $60 \mathrm{~min}$. Thus, it is obvious that $\mathrm{Mw}$ ranging from $180-189 \mathrm{KD}$ is significantly different than lower $\mathrm{Mw}$ values. [33] showed that the difference in the molecular weight is caused by the difference in the deacetylation degree, and the different sources of the chitosan. In addition, several factors in the production of chitosan, such as the high temperature, concentration of alkali, reaction time, previous treatment of the chitin, particle size, chitin concentration, dissolved oxygen concentration and shear stress may also influence the molecular weight of chitosan [26,35]. It was also reported by [26] that the molecular weight of commercial chitosan ranged between 100,000 to $1,200,000$ Daltons. In a study, [36] evaluated the antibacterial properties of chitosan with different MW (55 to $155 \mathrm{KD}$ ) but with same degree of deacetylation $(80 \% \pm 0.29)$, against $E$. coli with different concentrations. According to their result, all chitosans had antibacterial activity at concentrations over $200 \mathrm{ppm}$ though the antibacterial activity of low MW chitosan was higher than that of the high MW samples. [37] measured the antimicrobial activity of chitosan and chitooligosaccharides with different MW without acetylated groups. They observed high MW chitosans showed strong antimicrobial activity against Gram-positive bacteria, whereas, chitosans of $11 \mathrm{KD}$ and 20-30 KD molecular weights were most effective against Gram-negative bacteria. [38] reported that the effect of chitosan with MW below300 KD on Staphylococcus aureus was strengthened as the MW increased whereas, the antimicrobial effect on E. coli increased as the MW was decreased.

\subsubsection{Water Binding Capacity (WBC) and Fat Binding Capacity (FBC)}

The effect of extraction conditions on water binding capacity (WBC) and fat binding capacity (FBC) of chitosan is presented in Table (4). Different temperatures and times were attempted to obtain the best conditions for $\mathrm{WBC}$ and FBC of chitosan. The results showed that at $100^{\circ} \mathrm{C}$ for 60 min both (WBC) and (FBC) were significantly lower than all other time and temperature conditions. Results also indicated that by increasing temperature starting from $110^{\circ} \mathrm{C}$ upwards at different times (30 min and $60 \mathrm{~min}$ ) both (WBC) and (FBC) increased insignificantly. In the present study, the WBC and FBC under different conditions of temperature and time (of chitosan extracted from sqiulla shells) were higher (672.97 $863.24 \%$ and $503.01-661.79 \%$, respectively) than those findings by $[39,33]$ who reported that the water and fat binding capacities of different commercial chitosan were $355-805 \%$ and $217-535 \%$, respectively. Therefore, high percent of $\mathrm{WBC}$ and $\mathrm{FBC}$ confirms the fact that chitosan extracted from squilla shells is of a good quality.

Table (4). Effect of time and temperature on water binding capacity (WBC) and fat binding capacity (FBC) of Chitosan extracted from squilla shells.

\begin{tabular}{lll}
\hline Treatments & WBC (\%) & FBC (\%) \\
\hline $100^{\circ} \mathrm{C}(60 \mathrm{~min})$ & $672.98 \pm 29.32^{\mathrm{c}}$ & $503.05 \pm 6.58^{\mathrm{c}}$ \\
$110^{\circ} \mathrm{C}(60 \mathrm{~min})$ & $863.24 \pm 9.77^{\mathrm{a}}$ & $613.65 \pm 19.30^{\mathrm{ab}}$ \\
$120^{\circ} \mathrm{C}(30 \mathrm{~min})$ & $832.78 \pm 15.51^{\mathrm{a}}$ & $661.79 \pm 84.00^{\mathrm{a}}$ \\
$120^{\circ} \mathrm{C}(60 \mathrm{~min})$ & $802.68 \pm 38.91^{\mathrm{ab}}$ & $527.22 \pm 9.74^{\mathrm{bc}}$ \\
$130^{\circ} \mathrm{C}(30 \mathrm{~min})$ & $742.55 \pm 44.78^{\mathrm{bc}}$ & $564.75 \pm 19.87^{\mathrm{bc}}$ \\
$130^{\circ} \mathrm{C}(60 \mathrm{~min})$ & $776.12 \pm 51.17^{\mathrm{ab}}$ & $522.60 \pm 17.82^{\mathrm{bc}}$ \\
\hline
\end{tabular}

Mean with different superscripts in a row or columns are significantly different at $(\mathrm{p}<0.05)$ 


\subsection{Caroteinoed (as Astaxanthin)}

The astaxanthin content obtained from Squilla shells and female gonads is presented in Table (5). Results showed that squilla gonads had more content of astaxanthin $(14.01(\mu \mathrm{g} / \mathrm{g}$ wet wt.) than shells (10.10 $\mu \mathrm{g} / \mathrm{g}$ wet wt.). Therefore, gonads of squilla are a better source of astaxanthin compared to their shells which may be a promising source of astaxanthin. It was reported by [40] [41] that astaxanthin is the main ketocarotenoid responsible for the red-orange color in salmonids and crustacean and they found that astaxanthin was associated with reproduction and embryo development and also with protecting cells against oxidative damage. [40] reported that waste of $P$. borealis shrimp produced a yield of $14.8 \mathrm{mg} / 100 \mathrm{~g}$ dry weight. The different species of deep sea shrimps Aristeus alcocki shell waste is an excellent source of astaxanthin [42].

Table (5). Astaxanthin content obtained from Squilla shells and gonads.

\begin{tabular}{ll}
\hline Source & Astaxanthin $(\boldsymbol{\mu g} / \mathrm{g}$ wet wt.) \\
\hline Shells & $10.1 \pm 0.33$ \\
Gonads & $14.01 \pm 1.30$ \\
\hline
\end{tabular}

Data are expressed as mean \pm S.D. of triplicates

\section{Conclusion}

Squilla is an inexpensive and useful raw material for flesh and the production of chitin, chitosan and astaxanthin. Chitosan produced in the present study exhibit a high degree of deacetylation, a high solubility and an attractive molecular weight, and viscosity. Thus, squilla shells are promising raw material for the extraction of bioactive compounds (chitin and chitosan) as well as considerable amounts of natural carotenoids, mainly astaxanthin from the female gonads. It has been shown also from this study, that chitosan present a great variety of properties, allowing them to have a large number of applications, but at the same time the very complex behavior of these polymers is difficult to control. This study will attract the attention of entrepreneurs, industrialists, academicians and environmentalists.

\section{References}

[1] GAFRD," Statistical Records. "General Authority for fisheries Resources Development (GAFRD) - Ministry of Agriculture. (2013).

[2] K. Prabu and E. Natarajan. "Isolation and FTIR spectroscopy characterization of chitin from local sources." Advances in Applied Science Research. (2012) 3: 1870-1875.

[3] S. Kalyan, P. Sharma, V. Gery, N. Kunar and J. Varshney, "Recent advancement in Chitosan based formulations and its pharmaceutical application." Der pharmacia sinica. (2010) 1: 195-210.

[4] P. Sharma, S. Jain, G. Yadov and A. Sharma," Natural preservatives: Current insights and applications". Der Pharmacia Sinica. ( 2010) 1: 95-102
[5] A. Sanjiv, L. Sohan, S. Chetan and R, A Kamal," Synthesis, thermal and antimicrobial studies of chitosan/starch/poly (vinyl alcohol) ternary blend films". Der Chemica Sinica. (2011) 2: 75-.86.

[6] N. M. Sachindra, N. Bhaskar and N. S Mahendrakar," Recovery of carotenoids from shrimp waste in organic solvents". Waste Management. (2006) 26: 1092-1098.

[7] R. Sowmya and N. M. Sachindra, "Evaluation of antioxidant activity of carotenoid extract from shrimp processing byproducts by in vitro assays and in membrane model system". Food Chemistry. (2012) 134: 308-314.

[8] K. G. R. Nair, P. Madhavan and K. Gopakumar, " Info fish Marketing Digest, (1986) 4: 86, 20.

[9] G. A. F. Roberts, "In Advances in Chitin Science"; Domard, A.; Roberts, G. A. F.; Va ${ }^{\circ}$ rum, K. M., Eds.; Jacques Andre': Lyon, France. (1997) 2: 22-30.

[10] H. K. No, and S. P. Meyers," Preparation and characterization of chitin and chitosan." A review. Journal of Aquatic Food Product Technology. (1995) 4:27-52

[11] AOAC, "Official Methods of Analysis (17 $\left.7^{\text {th }}\right)$. Association Of Official Analytical Chemists. Washington, DC. (2005)

[12] R. F. Boyer, Modern Experimental Biochemistry, 2nd ed.; Benjamin/ Cummings Series in the Life Sciences and Chemistry: California. (1993) 199: 51-55.

[13] C. A. Black, "Methods of Soil Analysis, Part I Physical and mineralogical properties". American Society of Agronomy, Madison, Wisconsin (1965)

[14] A. Baxter, M. Dillon, K. D. Anthony Taylor and G. A. F. Roberts, "Improved method for (IR) determination of the degree of N-acetylation of chitosan". International Journal of Biological Macromolecules. (1992) 14: 166-169.

[15] H. K. No, J. W. Nah and S. P. Meyers," Effect of time / temperature treatment parameters on depolymerilyzation of chitosan." Journal of Applied Polymer Science. (2003). 87:1890-1894.

[16] M. S. Rao, K. A. Nyein, T. S. Trung and W. F. Stevens, "Optimum parameters for production of chitin and chitosan from squilla ( $S$. empusa)". Journal of Applied Polymer Science. (2007) 103: 3694-3700.

[17] S-O Fernandez-Kim," Physicochemical and functional properties of crawfish chitosan as affected by different processing protocols." Agricultural and Mechanical College, Louisiana State University (2004).

[18] J. C. Wang and J. E. Kinsella, " Functional properties of novel proteins: Alfalfa leaf protein". Journal of Food Science. (1976) 41: 286-292.

[19] SAS. SAS User's Guide, Version 8. Cary NC: SAS Institute (2001).

[20] K. G. R Nair, P. Madhavan and K. Gopakumar, In: Textbook of Fish Processing Technology, Indian Council of Agricultural Research, New Delhi. (2002) 467-483.

[21] K. Kurita, "Chitin and chitosan functional biopolymers from marine crustaceans", Marine Biotechnology. (2006) 8:203-226. 
[22] K. Gopakumar,"Textbook of fish processing technology." Indian council of agricultural research New Delhi. (2002) 467-483.

[23] M. Rhazi, J. Desbrie'res, A. Tolaimate, A. Alagui and P. Vottero, "Investigation of different natural sources of chitin: influence of the source and deacetylation process on the physicochemical characteristics of chitosan". Polym. Int. (2000) 49: 337-344.

[24] N. Thirunavukkarasu, K. Dhinamala and R. I. Moses, "Production of chitin from two marine stomatopods Oratosquilla spp. (Crustacea)". J. Chem. Pharm. Res. (2011) 3:353-359.

[25] T. A. Khan, K. K Peh and H.S. Ch'ng,".Reporting degree of deacetylation values of chitosan: the influence of analytical methods." J Pharm Pharmaceutics Sci. (2002) 5:205-12.

[26] Q. Li, E. T. Dunn, E. W. Grandmaison, and M. F. A. Goosen," Applications and properties of chitosan." Journal of Bioactive Compatible Polymers. (1992) 7: 370-397.

[27] Alimuniar and Zainuddin, "An economical technique for producing chitosan." In Advances in Chitin and Chitosan, C. J. Brine, P.A. Sanford, and J.P. Zikakis (Ed.), (1992) p.627. Elsevier Applied Science, Essex, UK.

[28] Y. J. Jeon, J. Y. V. A. Kamil and F. Shahidi, "Chitosan as an edible invisible film for quality preservation of herring and Atlantic cod." Journal of Agricultural and Food Chemistry, (2002) 50: 5167-5178.

[29] H. K. No, S.P. Meyers, W. Prinyawiwatkul and Z. Xu,. Application of chitosan for improvement of quality and shelf life of foods." A review J. Food Sci. (2007)72: 87-100.

[30] R. Prashanth and R. Tharanathan,"Chitin/chitosan: modifications and their unlimited application potential- an overview". Trends Food Sci Tech. (2007) 18: 117-31.

[31] G. Lamarque, M. Cretenet, C. Viton and A. Domard, "New route of deacetylation of $\alpha$ - and $\beta$-chitins by means of freeze-pump out-thaw cycles." Biomacromolecules. (2005) 6: $1380-1388$.

[32] K. Kurita," Controlled functionalization of polysaccharide chitin." Prog. Poly. Sci. (2001) 26: 1921-1971.
[33] A. Kucukgulmez, M. Celik, Y. Yanar, D. Sen, H. Polat and A. Eslem Kadak, "Physicochemical characterization of chitosan extracted from Metapenaeus stebbingi shells." Food Chemistry. (2011) 126:1144-1148.

[34] M. T. Yen, J.-H. Yang and J. L. Mau, "Physicochemical characterization of chitin and chitosan from crab shells". Carbohydrate Polymers. (2009) 75: 15-21.

[35] S. V. Nemtsev, A. I . Gamzazade, S. V. Rogozhin, V. M. Bykova and V. P. Bykov, "Deacetylation of chitin under homogeneous conditions." Applied Biochemistry and Microbiology. (2002) 38: 521-526.

[36] N. Liu, X.-G. Chen, H. J Park, C.-G Liu, X. H. Meng and L. J. $\mathrm{Yu}$, "Effect of $\mathrm{Mw}$ and concentration of chitosan on antibacterial activity of Escherichia coli." Carbohydrate Polymers. (2006) 64: 60-65.

[37] Y. Omura, M. Shigemoto, T. Akiyama, H. Saimoto, Y. Shigemasa, I Nakamura and T. Tsuchido," Reexamination of antimicrobial activity of chitosan having different degrees of acetylation and molecular weights." Advances in Chitin Sci. (2002) 6: 273-274.

[38] L. O. Y. Zheng and J. F. Zhu, "Study on antimicrobial activity of chitosan with different molecular weights". Carbohydrate Polymer. (2003) 54: 527-530.

[39] H. K. No, Y. I. Cho, H. R. Kim and S. P. Meyers." Effective deacetylation of chitin under conditions of $15 \mathrm{psi} / 121^{\circ} \mathrm{C}$ ". Journal of Agricultural and Food Chemistry. (2000) 48: 2625-2627.

[40] F. Shahidi and J. Synowiecki," Isolation and characterization of nutrients and value-added products from snow crab (Chinoecetes opilio) and shrimp (Pandalus borealis) processing discards". Journal of Agricultural and Food Chemistry. (1991) 39:1527-1532.

[41] I. Higuera-Ciapara, L. Felix-Valenzuela, F. M. Goycoolea and W. Argu"elles-Monal, "Microencapsulation of astaxanthin in a chitosan matrix." Carbohydrate Polymers. (2004) 56: 41-45.

[42] S. Sindhua and P. M. Sherief," Extraction, characterization, antioxidant and anti-Inflammatory properties of carotenoids from the shell waste of Arabian Red Shrimp Aristeus alcocki, Ramadan 1938". The Open Conference Proceedings Journal. (2011) 2: 95-103. 